\title{
Sensitivitas dan spesifisitas food consumption score dalam mengidentifikasi rawan pangan dengan parameter status gizi balita
}

\author{
Aklesta Leni Firna ${ }^{1,2^{*}}$, Azis Nur Bambang ${ }^{3}$, Diana Nur Afifah ${ }^{2}$ \\ ABSTRACT \\ Background : Food consumption score (FCS) was one of indicators to measure the food insecurity that included some \\ elements from food access and food consumption, but the sensitivity was different in each area so it was needed to do the \\ sensitivity and specificity tests with the high precision and accuracy of parameter. \\ Objectives : To do the sensitivity and specificity test of food consumption score to identify the food insecurity with parameter \\ status of toddlers' nutrition anthropometrically. \\ Methods : Cross sectional study with total subjects 517 toddlers. Status of toddlers' nutrition was counted according to zscore \\ WHZ, WAZ, and HAZ. The FCS score was counted according to WFP formula. \\ Results : Sensitivity (Se) and specificity (Sp) FCS test with parameter of WHZ, WAZ, HAZ as followed $\mathrm{Se}=0 \mathrm{Sp}=\geq 90 \%$. \\ Conclusion: The cut-off point of FCS that was set by WFP was non-sensitive in identifying the food insecurity with parameter \\ status of toddlers' nutrition.
}

Keywords : food consumption score, food insecurity, sensitivity, spesifisity, nutrition status

\begin{abstract}
ABSTRAK
Latar Belakang : Food consumption score (FCS) merupakan salah satu indikator untuk mengukur kerawanan pangan yang mencakup beberapa elemen dari akses pangan dan konsumsi pangan. Namun sensistivitasnya berbeda di setiap wilayah sehingga perlu dilakukan uji sensitivitas dan spesifisitas dengan parameter yang memiliki presisi dan akurasi tinggi.

Tujuan : Melakukan uji sensitivitas dan spesifitas FCS dalam mengidentifikasi rawan pangan dengan parameter status gizi balita secara antopometri.

Metode : Cross sectional study dengan jumlah subjek 517 balita. Status gizi balita dihitung berdasarkan zscore BB/TB, BB/U, dan TB/U. Skor FCS dihitung berdasarkan rumus dari World Food Programme (WFP).

Hasil : Hasil uji sensitivitas dan spesifisitas FCS dengan parameter BB/TB, BB/U, TB/U sebagai berikut $S e=0 \quad S p=>90 \%$.

Simpulan : Cut off point FCS yang ditetapkan WFP tidak sensitif dalam mengidentifikasi rawan pangan dengan parameter status gizi balita.
\end{abstract}

Kata kunci : food consumption score, kerawanan pangan, sensitivitas, spesifisitas, status gizi

\section{PENDAHULUAN}

Kerawanan pangan masih sering terjadi baik di negara maju maupun negara berkembang yang berdampak pada status kesehatan dan gizi. Kerawanan pangan dapat berpengaruh terhadap kesehatan baik secara langsung dan tidak langsung melalui perubahan status gizi baik kekurangan atau kelebihan gizi. ${ }^{1}$ Penelitian di negara maju menyatakan bahwa kerawanan pangan berhubungan dengan kelebihan gizi yang berakibat pada rendahnya status kesehatan, sedangkan penelitian di negara berkembang kerawanan pangan lebih berhubungan dengan kekurangan gizi. $^{1-4}$

\footnotetext{
1. Badan Ketahanan Pangan, Kementerian Pertanian RI. Jln. Harsono RM No.3 Ragunan, Jakarta Selatan 12550

2. Departemen Ilmu Gizi, Fakultas Kedokteran, Universitas Diponegoro. Jl. Prof. H. Soedarto, Tembalang, Semarang 50275

3. Departemen Perikanan Tangkap, Fakultas Perikanan dan Kelautan, Universitas Diponegoro. Jl. Prof. $H$. Soedarto, Tembalang, Semarang 50275

*Korespondensi : email : aklesta27@gmail.com
}

Kerawanan pangan berdampak ganda bagi status gizi balita di Indonesia, di satu sisi masih banyak yang mengalami kekurangan gizi dan disisi lain jumlah balita yang mengalami kelebihan gizi juga meningkat. Data penilaian status gizi tahun 2015 menunjukan bahwa sebanyak 29,9\% anak balita Indonesia mengalami stunting, $14,9 \%$ gizi kurang, $3,8 \%$ gizi buruk, $8,2 \%$ kurus, dan 3,7\% sangat kurus. ${ }^{5}$ Selain itu, berdasarkan riset UNICEF Indonesia pada tahun 2012 jumlah balita yang mengalami kelebihan gizi sebesar $12 \%{ }^{6}$

Kerawanan pangan antara lain dapat diukur dengan tingkat konsumsi dan status gizi berdasarkan indeks antropometri. ${ }^{7,8}$ Kerawanan pangan dibedakan menjadi dua yaitu kerawanan pangan kronis dan kerawanan pangan transien. Indikator antropometri yang dapat menggambarkan rawan pangan kronis adalah $\mathrm{TB} / \mathrm{U}$ untuk anak balita. Indikator TB/U dapat menggambarkan kekurangan atau ketidakcukupan asupan konsumsi dalam waktu yang lama, sedangkan indikator antropometri yang dapat menggambarkan kondisi rawan pangan transien adalah $\mathrm{BB} / \mathrm{TB}$ untuk balita. $^{9-11}$ 
Metode Food Consumption Score (FCS) merupakan metode yang dikembangkan oleh World Food Programme (WFP) yang merupakan skor komposit berdasarkan pada keragamaan konsumsi makanan, frekuensi makan dan asupan zat gizi penting lainnya dari berbagai jenis kelompok makanan. ${ }^{12-14}$ FCS merupakan salah satu indikator untuk mengukur kerawanan pangan rumah tangga atau individu karena mencakup beberapa elemen dari akses pangan dan konsumsi pangan. Secara kualitatif metode FCS lebih mudah dan lebih sederhana untuk pengambilan data konsumsi pangan rumah tangga/individu. ${ }^{15}$ Pernyataan tersebut didukung oleh hasil penelitian Tiwari et al, yang membandingkan beberapa metode yang digunakan sebagai indikator untuk menilai ketahanan pangan di lima negara berbeda di wilayah Asia Selatan dan Afrika, hasil penelitian menyatakan bahwa metode FCS mampu memberikan informasi yang lebih baik tentang konsumsi pangan, lebih sederhana, hemat biaya, dan pengumpulan data yang lebih mudah jika dibandingkan dengan metode lainnya. ${ }^{16}$ Kelemahan metode FCS antara lain hanya dapat menggambarkan konsumsi energi dan protein sehingga tidak dapat menggambarkan konsumsi zat gizi mikro. ${ }^{17-18}$ Uji sensitivitas dan spesifisitas terhadap metode food consumption score masih perlu dilakukan untuk mengidentifikasi kekonsistenannya dalam mengidentifikasi kerawanan dan ketahanan pangan. Hal ini perlu dilakukan karena berdasarkan uji validasi FCS yang dilakukan di tiga negara yaitu Burundi, Haiti dan Sri Lanka menunjukkan bahwa FCS dapat digunakan untuk menilai ketahanan pangan rumah tangga, namun cut-off point yang direkomendasikan oleh WFP terlalu rendah ketika dibandingkan dengan konsumsi kalori per kapita. ${ }^{18}$ Hasil penelitian di Bogor juga menyatakan bahwa FCS tidak mampu mengidentifikasi rumah tangga rawan pangan karena sensitivitasnya sangat rendah yaitu 0 persen. ${ }^{19}$ Selain itu, cut off point FCS yang ditetapkan WFP memiliki sensitivitas yang berbedabeda di setiap wilayah/negara sehingga harus dilakukan perhitungan cut off point baru di masingmasing wilayah tersebut agar sensitif dalam menilai kondisi rawan pangan. ${ }^{17-18}$

Agar diperoleh sensitivitas dan spesifisitas yang baik, maka metode penilaian konsumsi harus diuji dengan parameter yang memiliki presisi tinggi. Antropometri merupakan penilaian status gizi yang memiliki presisi cukup baik dan dapat menggambarkan kekurangan energi protein. Oleh sebab itu perlu dilakukan uji sensitivitas dan spesifisitas FCS dalam menilai kerawanan pangan dengan menggunakan parameter status gizi secara antropometri pada balita. Penelitian ini bertujuan untuk melakukan uji sensitivitas dan spesifisitas Food
Consumption Score dalam mengidentifikasi rawan pangan dengan parameter status gizi balita.

\section{BAHAN DAN METODE}

Desain penelitian adalah uji diagnostik dengan rancangan cross sectional. Penelitian dilakukan di Kabupaten Wonosobo, Jawa Tengah dengan pertimbangan bahwa presentase keluarga miskin di Kabupaten Wonosobo tertinggi di Jawa Tengah yaitu $22,08 \%$ dan Kabupaten Wonosobo memiliki karakterstik pedesaan dimana kerawanan pangan umumnya banyak terjadi di daerah pedesaan dan pada keluarga miskin. Penelitian dilakukan dari bulan Januari - April 2017.

Jumlah subjek pada penelitian ini adalah sebanyak 517 balita yang diperoleh dengan rumus perhitungan sampel minimal untuk uji diagnostik dengan tingkat kesalahan 5\%. Pemilihan subjek dilakukan dengan metode cluster sampling dan berdasarkan kriteria inklusi balita berusia 2-5 tahun, tidak memiliki cacat bawaan/kelainan yang dapat mengganggu pertumbuhan dan perkembangan anak, berat badan lahir balita $\geq 2600$ gram, balita dalam tiga bulan terakhir tidak mengalami infeksi berat, balita dalam satu bulan terakhir tidak mengalami infeksi ringan.

Data status gizi diperoleh melalui pengukuran berat badan balita dengan timbangan injak digital dengan ketelitian $0,1 \mathrm{~kg}$ dan tinggi badan balita diukur menggunakan stadiometer. Data karakteristik subjek, skor konsumsi pangan (FCS) diperoleh dengan wawancara terhadap ibu menggunakan kuesioner. Untuk data tingkat konsumsi diperoleh dengan food recall 2 × 24 jam dan FFQ semi kuantitaif.

Pengolahan data status gizi balita dilakukan dengan membandingkan hasil pengukuran $\mathrm{TB} / \mathrm{BB}$, $\mathrm{TB} / \mathrm{U}, \mathrm{BB} / \mathrm{U}$ dengan standar Z-score yang ditetapkan oleh WHO. Kriteria rawan pangan yang ditetapkan adalah apabila Z-score <-2SD. Data untuk menghitung skor konsumsi pangan diperoleh dengan wawancara menggunakan kuesioner frekuensi konsumsi selama 7 hari terakhir, berdasarkan data tersebut kemudian dilakukan perhitungan sebagai berikut: (1) Semua jenis pangan dikelompokkan ke masing-masing kelompok pangan (serealia dan umbiumbian, biji-bijian, sayur-sayuran, buah-buahan, daging dan ikan, susu, gula, minyak, dan bumbubumbu); (2) Frekuensi masing-masing jenis pangan yang dikonsumsi dikelompokan berdasarkan kelompok pangan yang sama kemudian dijumlahkan. Maximal penjumlahan adalah 7; (3) Skor penjumlahan masing-masing kelompok pangan dijumlahkan, sehingga diperoleh skor konsumsi pangan atau FCS untuk semua jenis pangan yang dikonsumsi. Skor dikategorikan ke dalam tiga kelompok, yaitu: poor (0- 
$28)$, borderline $(28,5-42)$ dan acceptable (> 42) sebagaimana yang telah ditetapkan WFP. Data konsumsi hasil recall $2 \times 24$ jam dan FFQ semi kuantitatif dihitung dengan menggunakan program nutrisurvey kemudian dibandingkan dengan kecukupan energi protein individu untuk menghitung tingkat kecukupannya. Perhitungan kecukupan energi dan protein menggunakan rumus sebagai berikut: ${ }^{20,21}$

Tabel 1. Model Estimasi Kecukupan Energi Per Individu

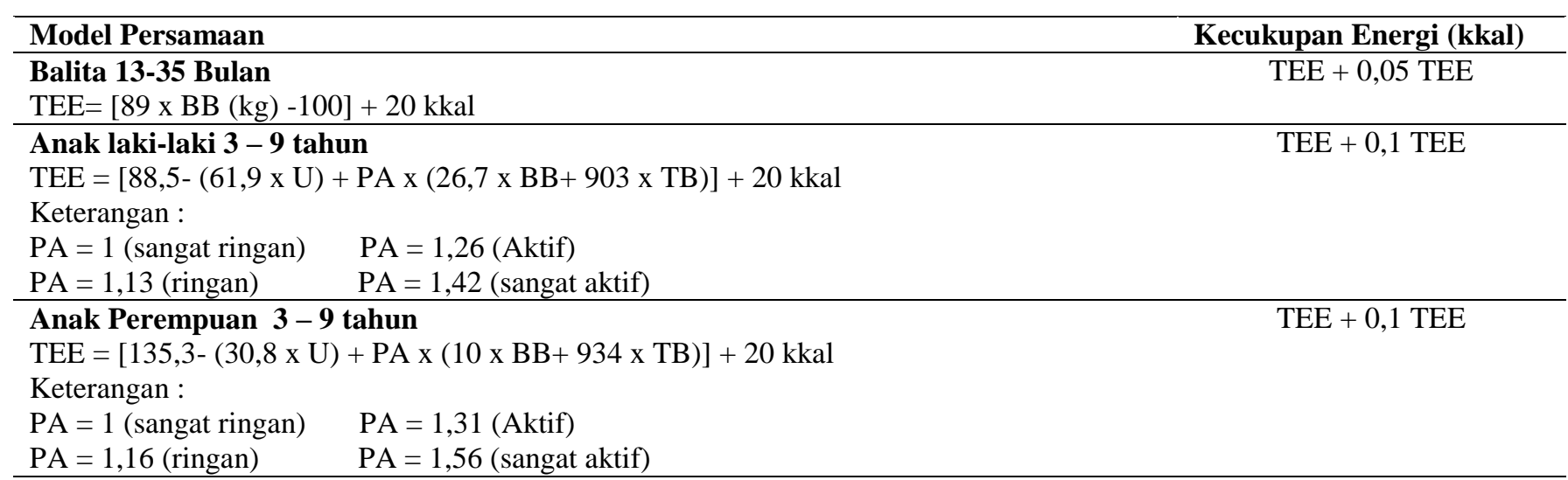

Keterangan : $\mathrm{U}=$ umur $($ tahun), $\mathrm{BB}=$ berat badan $(\mathrm{kg}), \mathrm{TB}=$ tinggi badan $(\mathrm{m}) ; \mathrm{TEE}=$ Total Energy Expenditure $=$ total pengeluaran energi $; \mathrm{PA}=$ koefisien aktivitas fisik

Rumus perhitungan kecukupan protein $:^{20,21}$

\section{Kecukupan protein $=($ AKP $\times$ BB $) \times$ Faktor koreksi} mutu protein

Keterangan :

$\mathrm{AKP}=$ Angka kecukupan protein $(\mathrm{g} / \mathrm{kgBB} / \mathrm{hari})$

$\mathrm{BB}=$ Berat Badan Aktual (kg)

Faktor koreksi mutu protein umum $=1,5$ bagi anak dan remaja

Sensitivitas dan spesifisitas dihitung dengan menggunakan tabel $2 \times 2$. Sensitivitas $(\mathrm{Se})$ dihitung dengan rumus $\mathrm{Se}=\mathrm{TP} /(\mathrm{TP}+\mathrm{FN})$. Sedangkan Spesifisitas $(\mathrm{Sp})=\mathrm{TN} /(\mathrm{TN}+\mathrm{FP})$; dimana $\mathrm{TP}=$ true positive yaitu balita yang benar-benar dikategorikan rawan pangan baik dari status gizinya maupun dari tingkat kecukupan konsumsinya, $\mathrm{TN}=$ true negative yaitu balita yang dinyatakan normal baik dari status gizi maupun tingkat kecukupan gizinya, $\mathrm{FN}=$ false negative yaitu balita yang dinyatakan rawan pangan menurut status gizi, tetapi tidak rawan pangan menurut tingkat kecukupan gizinya, dan $\mathrm{FP}=$ false positive adalah balita yang dinyatakan rawan pangan menurut tingkat kecukupan gizi, tetapi tidak rawan pangan menurut status gizinya. Penelitian ini telah ditelaah dan mendapat persetujuan dari Komisi Etik Penelitian Kesehatan (KEPK) Fakultas Kedokteran Universitas Diponegoro Semarang dengan diterbitkannya sertifikat ethical clearance No. 10/EC/FK-RSDK/I/2017.

\section{HASIL}

\section{Karakteristik Subjek}

Jumlah subjek balita laki-laki dan perempuan hampir sama yaitu 50,7\% laki-laki dan 49,3\% perempuan. Subjek balita paling banyak $(44,1 \%)$ berusia 48-60 bulan. Berdasarkan status gizi $\mathrm{BB} / \mathrm{TB}$ sebanyak $6 \%$ balita kurus dan 5,2\% gemuk. Berdasarkan status BB/U jumlah subjek yang mengalami kekurangan gizi sebanyak 9,9\% dan 5,2\% mengalami kelebihan gizi. Berdasarkan rasio TB/U sebanyak $26,1 \%$ subjek mengalami stunting (Tabel 2).

\section{Hubungan FCS dan Tingkat Kecukupan Energi Protein Hasil recall $2 \times 24$ jam dan FFQ-SQ}

Berdasarkan perhitungan diperoleh bahwa hampir seluruh subjek $(99,2 \%)$ memiliki skor konsumsi pangan (FCS) yang tinggi yaitu di atas 42 . Hasil uji korelasi spearman antara skor FCS dan tingkat kecukupan energi berdasarkan hasil food recall $2 \times 24$ jam, FFQ-SQ dan tingkat kecukupan protein FFQ-SQ menunjukan nilai koefisien korelasi $>0,10$ dan nilai signifikansi $\mathrm{p}<0,05$ hal ini berarti terdapat hubungan positif antara skor FCS dengan tingkat kecukupan energi recall $2 \times 24$ jam dan tingkat kecukupan energi protein FFQ-SQ namun kekuatan hubungannya kurang kuat, demikian pula dengan hasil uji korelasi pearson antara FCS dengan tingkat kecukupan protein recall $2 \times 24$ jam juga menunjukan nilai $r>0,10$ dan $p<0,001$.

\section{Sensitivitas dan Spesifisitas Food Consumption Score}

Tabel 3 menunjukan bahwa FCS tidak mampu mengidentifikasi rawan pangan dengan parameter status gizi balita karena sensitivitasnya (Se) sangat rendah yaitu 0 persen. Sensitivitas 0\% disebabkan semua subjek memiliki skor FCS yang baik. Spesifisitas (Sp) FCS dalam mengidentifikasi tahan pangan dengan parameter status gizi sangat baik yaitu 
diatas $90 \%$, hal ini berarti FCS memiliki kemampuan lebih dari $90 \%$ dalam mengidentifikasi tahan pangan namun tidak mampu mengidentifikasi rawan pangan. Rendahnya sensitivitas pada FCS disebabkan rendahnya cut off point yang ditetapkan oleh WFP dimana dinyatakan rawan pangan apabila FCS kurang dari 28 , sedangkan pada penelitian ini tidak terdapat subjek yang memiliki status gizi kurang dengan nilai FCS kurang dari 28. Selain itu berdasarkan hasil uji mann whitney tidak terdapat perbedaan rerata skor FCS pada subjek yang mengalami kurus, gizi kurang, dan normal $(p>0,05)$. Perbedaan rerata skor FCS terdapat pada subjek yang stunting dan normal $(\mathrm{p}<0,05)$.

Tabel 2. Karakteristik Subjek Balita

\begin{tabular}{|c|c|c|c|c|}
\hline Karakteristik & $\mathbf{N}$ & $\%$ & Mean \pm SD & Median (Min-Max) \\
\hline \multicolumn{5}{|l|}{ Jenis Kelamin } \\
\hline Laki-laki & 262 & 50,7 & - & - \\
\hline Perempuan & 255 & 49,3 & & \\
\hline \multicolumn{5}{|l|}{ Umur } \\
\hline $24-35$ bulan & 138 & 26,7 & & \\
\hline $36-47$ bulan & 151 & 29,2 & $43,5 \pm 10,7$ & $45(24-60)$ \\
\hline $48-60$ bulan & 228 & 44,1 & & \\
\hline \multicolumn{5}{|l|}{$\mathrm{BB} / \mathrm{TB}$} \\
\hline Kurus $($ Zscore $<-2 \mathrm{SD})$ & 31 & 6,0 & & $-0,16$ \\
\hline Normal (Zscore $-2-2$ SD) & 459 & 88,8 & $-0,08 \pm 1,26$ & $(-3,64-4,64)$ \\
\hline Gemuk (Zscore > 2 SD) & 27 & 5,2 & & \\
\hline \multicolumn{5}{|l|}{$\mathrm{BB} / \mathrm{U}$} \\
\hline Gizi Kurang (Zscore $<-2 \mathrm{SD}$ ) Gizi & 50 & 9,7 & & $-0,75$ \\
\hline Baik (Zscore $-2-2$ SD) & 456 & 88,2 & $-0,67 \pm 1,07$ & $(-3,71-3,16)$ \\
\hline Gizi Lebih (Zscore > 2 SD) & 11 & 2,1 & & \\
\hline \multicolumn{5}{|l|}{$\mathrm{TB} / \mathrm{U}$} \\
\hline Pendek $($ Zscore $<-2 S D)$ & 134 & 25,9 & & $-1,09$ \\
\hline Normal (Zscore $-2-2$ SD) & 369 & 71,4 & $-1,06 \pm 1,36$ & $(-3,97-3,29)$ \\
\hline Tinggi (Zscore > $2 \mathrm{SD})$ & 14 & 2,7 & & \\
\hline
\end{tabular}

Tabel 3. Sensitivitas dan Spesifisitas FCS dalam Mengidentifikasi Kekurangan dan Kelebihan Gizi

\begin{tabular}{llccccc}
\hline & & Median & (Min-Max) & $\mathbf{p}^{*}$ & Se & Sp \\
\hline BB/TB & Kurus & 88 & $40-112$ & 0,776 & 0 & 0,998 \\
& Normal & 88 & $24-112$ & & & \\
\hline BB/U & Gizi Kurang & 86,75 & $40-112$ & 0,07 & 0 & 0,998 \\
& Gizi Baik & 88 & $24-112$ & & & \\
\hline TB/U & Pendek & 81,5 & $41-112$ & 0,01 & 0 & 0,997 \\
& Normal & 89 & $24-112$ & & & \\
\hline
\end{tabular}

${ }^{*}$ Uji Mann Whitney

Tabel 4. Titik Potong Paling Optimal Skor FCS dalam Mengidentifikasi Rawan Pangan dengan Parameter Status Gizi Balita

\begin{tabular}{llcccc}
\hline & & Cut off Point & Sensitivitas & Spesifisitas & Akurasi \\
\hline $\mathrm{BB} / \mathrm{TB}$ & Kurus & 88 & $48,4 \%$ & $51,2 \%$ & $51,5 \%$ \\
\hline $\mathrm{BB} / \mathrm{U}$ & Gizi Kurang & 87 & $50 \%$ & $49,8 \%$ & $50 \%$ \\
\hline $\mathrm{TB} / \mathrm{U}$ & Stunting & 87 & $43,3 \%$ & $44,9 \%$ & $40,6 \%$ \\
\hline
\end{tabular}

Cut Off Point FCS yang Optimal dalam Mengidenifikasi Rawan Pangan Dengan Parameter Status Gizi Balita

Tabel 4 menunjukan titik potong skor FCS yang paling optimal dalam mengidentifikasi rawan pangan dengan parameter status gizi balita. Skor yang paling optimal untuk mengidentifikasi kurus, gizi kurang, dan stunting adalah $87-88$, namun akurasinya hanya berkisar antara 40,6\% - 51,5\%.

Gambar 1 memperlihatkan bahwa titik potong yang paling optimal antara sensitivitas dan spesifisitas FCS dalam mengidentifikasi rawan pangan dengan parameter status gizi kurus adalah pada skor 88 yaitu dengan sensitivitas sebesar $48,4 \%$, spesifisitas $51,2 \%$ dan akurasi $51,5 \%$. 

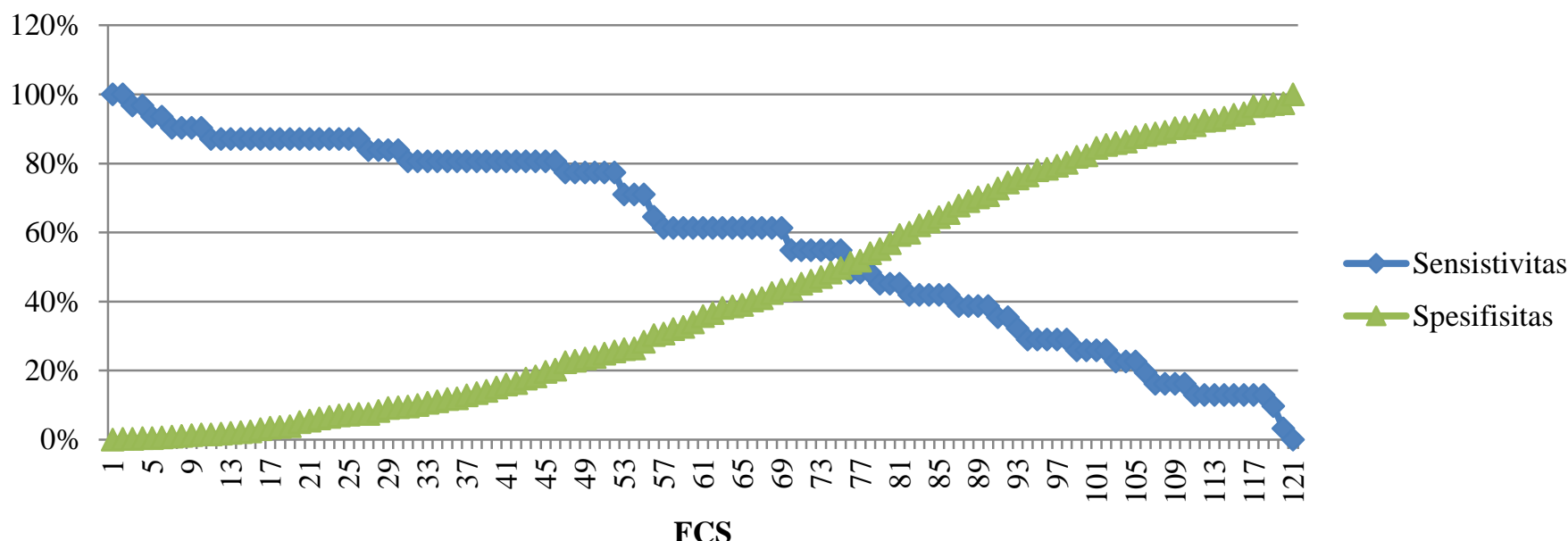
- Spesifisitas

Gambar 1. Sensitivitas dan Spesifisitas FCS dalam Mengidentifikasi Kurus

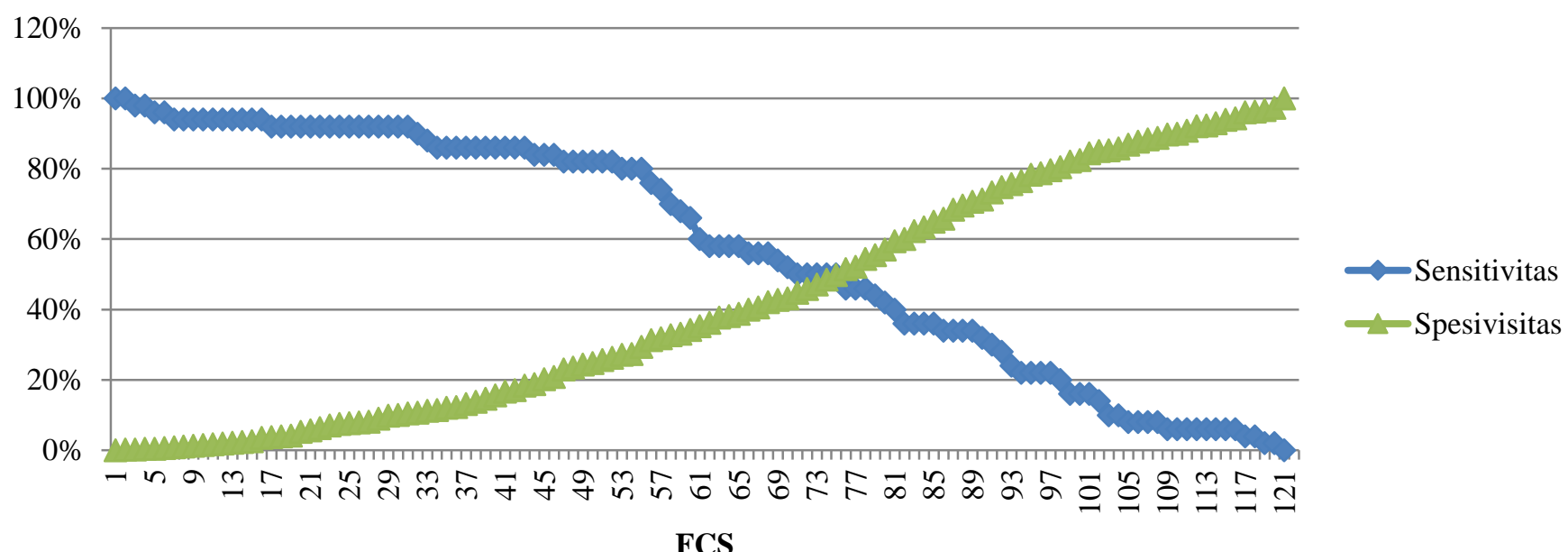

Gambar 2. Sensitivitas dan Spesifisitas FCS dalam Mengidentifikasi Gizi Kurang

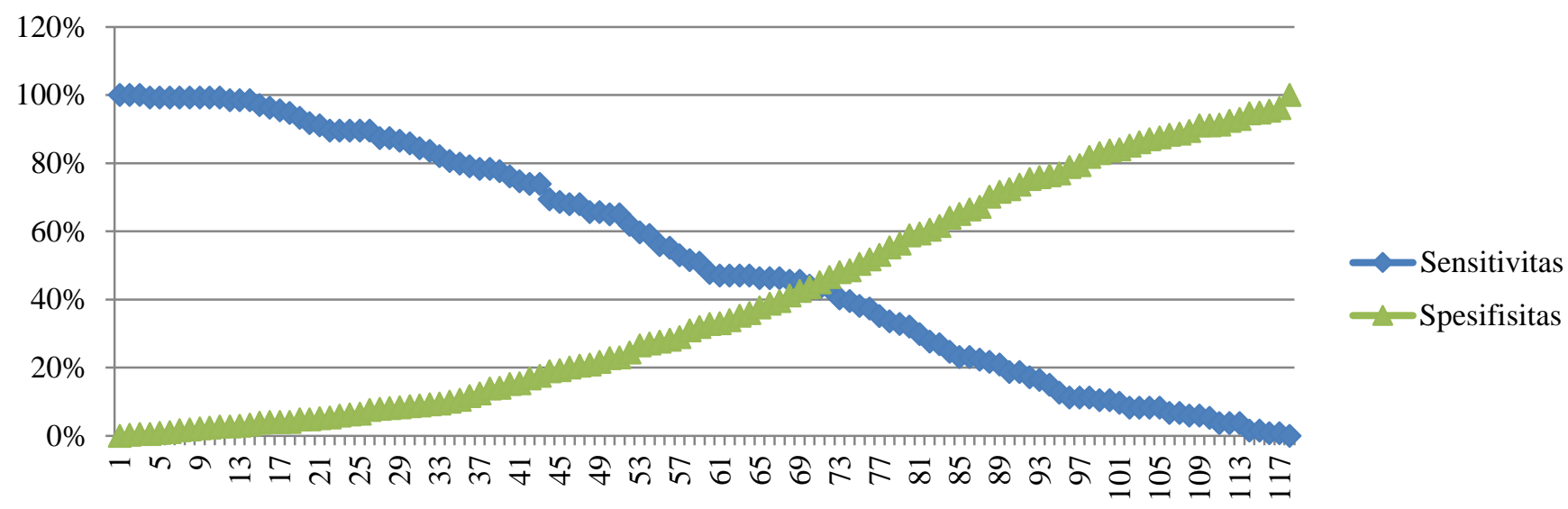

\section{FCS}

\section{Gambar 3. Sensitivitas dan Spesifisitas FCS dalam Mengidentifikasi Stunting}

Gambar 2 menunjukan titik potong yang paling optimal untuk mengidentifikasi rawan pangan dengan parameter status gizi kurang adalah pada skor 87 dengan sensitivitas sebesar $50 \%$, spesifisitas $49,8 \%$ dan akurasi $50 \%$.
Gambar 3 menunjukan titik potong yang paling optimal untuk mengidentifikasi rawan pangan dengan parameter stunting yaitu juga pada skor 87 dengan sensitivitas sebesar 43,3\%, spesifisitas 44,9\% dan akurasi $40,6 \%$. 


\section{PEMBAHASAN}

Rata-rata konsumsi energi protein dari hasil FFQ-SQ sedikit lebih tinggi daripada rata-rata hasil recall, karena pada FFQ-SQ umumnya jenis pangan yang dilaporkan lebih banyak dan lebih beragam dibanding recall. Peningkatan keragaman pangan sebesar $1 \%$ dapat meningkatkan konsumsi sebesar $1 \% .{ }^{22,23}$ FCS berubungan dengan tingkat kecukupan energi namun hubungannya kurang kuat, hal ini sesuai dengan hasil penelitian Margarita L dan Astrid M yang menyatakan bahwa FCS sangat signifikan menggambarkan konsumsi energi namun tidak memiliki hubungan yang kuat dengan konsumsi energi. ${ }^{22,23}$ Perbedaan rerata skor FCS terdapat pada subjek yang stunting dan normal $(\mathrm{p}<0,05)$ hal ini sesuai dengan penelitian sebelumnya yang menyatakan bahwa FCS memiliki hubungan yang signifikan dengan kejadian kurang gizi kronis (stunting) karena FCS menggambarkan kualitas konsumsi. ${ }^{22}$

Ketidaksensitivan FCS dalam mengidentifikasi rawan pangan juga dinyatakan dalam penelitian Margarita L dan Astrid M bahwa FCS menggambarkan konsumsi energi namun sensitivitasnya berbeda-beda di 5 negara dimana cut off point minimal yang paling optimal dalam mengidentifikasi rawan pangan adalah dibawah 50 . Uji validasi FCS yang dilakukan di tiga negara yaitu Burundi, Haiti dan Sri Lanka menunjukkan bahwa FCS dapat digunakan untuk menilai kerawanan pangan rumah tangga, namun cut-off point yang direkomendasikan oleh WFP terlalu rendah ketika dibandingkan dengan konsumsi kalori per kapita. ${ }^{18}$

\section{Cut Off Point FCS yang Optimal dalam Mengidenifikasi Rawan Pangan Dengan Parameter Status Gizi Balita}

Rendahnya sensitivitas FCS disebabkan cut-off point yang ditetapkan oleh WFP untuk mengkategorikan poor, borderline dan acceptable terlalu rendah sehingga FCS tidak dapat mengidentifikasi rawan pangan dengan parameter status gizi balita. Gambar 1 memperlihatkan bahwa titik potong yang paling optimal antara sensitivitas dan spesifisitas FCS dalam mengidentifikasi rawan pangan dengan parameter status gizi kurus adalah pada skor 88 yaitu dengan sensitivitas sebesar $48,4 \%$, spesifisitas 51,2\% dan akurasi 51,5\%. Gambar 2 menunjukan titik potong yang paling optimal untuk mengidentifikasi rawan pangan dengan parameter status gizi kurang adalah pada skor 87, dan pada gambar 3 menunjukan titik potong yang paling optimal untuk mengidentifikasi rawan pangan dengan parameter stunting yaitu juga pada skor 87. Titik potong paling optimal untuk mengidentifikasi rawan pangan berada pada kisaran 87-88, hal ini hampir sama dengan hasil penelitian Sembiring yang menyatakan bahwa titik potong yang paling tepat menggambarkan tingkat kecukupan energi adalah pada skor 89 dimana memiliki sensitivitas sebesar $70 \%$ dan spesifisitas $67 \% .^{22,23}$

Berdasarkan titik potong paling optimalnya FCS memiliki sensitivitas lebih tinggi dalam mengidentifikasi gizi kurang dibandingkan dalam mengidentifikasi gizi kurus dan stunting, sedangkan berdasarkan akurasinya FCS memiliki akurasi yang rendah dalam mengidentifikasi rawan pangan dengan parameter status gizi balita karena akurasinya $<60 \%$ (Tabel 4). Rendahnya akurasi FCS disebabkan pada metode FCS hanya memperhitungkan kualitas namun tidak memperhitungkan kuantitas konsumsi. ${ }^{17}$

\section{SIMPULAN}

Berdasarkan hasil penelitian dapat disimpulkan bahwa cut off point FCS yang ditetapkan oleh WFP tidak sensitif dalam mengidentifikasi rawan pangan karena nilai sensitivitasnya 0. Food Consumption Score dapat digunakan dan lebih sensitif apabila cut off point-nya dinaikkan menjadi 87-88.

\section{SARAN}

Perlu dilakukan uji sensitivitas dan spesifitas skor Food Consumption Score (FCS) dengan cut off point yang baru (87-88). Hal tersebut bertujuan untuk mengidentifikasi rawan pangan dengan menggunakan parameter gabungan antara status gizi dan tingkat kecukupan energi protein.

\section{DAFTAR PUSTAKA}

1. Mohamadpour M, Mohd Sharif Z, Avakh Keysami M. Food insecurity, health and nutritional status among sample of palmplantation households in Malaysia. J Heal Popul Nutr. 2012;30(3):291-302.

2. Mutisya M, Kandala N-B, Ngware MW, Kabiru $\mathrm{CW}$. Household food (in) security and nutritional status of urban poor children aged 6 to 23 months in Kenya. BMC Public Health. 2015;15(1):1052.

3. Kirkpatrick SI, Tarasuk V. Food insecurity is associated with nutrient inadequacies among Canadian adults and adolescents. J Nutr. 2008;138(3):604-12.

4. Weigel MM, Armijos RX, Racines M, Cevallos W. Food insecurity is associated with undernutrition but not overnutrition in ecuadorian women from low-income urban neighborhoods. J Environ Public Health. 2016;2016.

5. Direktorat jendral kesehatan masyarakat. 
Pemantauan status gizi dan indikator kinerja gizi. Kemenkes RI; 2016.

6. Unicef. Kesehatan Ibu \& Anak. [Internet]. 2012. Available from: https://www.unicef.org/indonesia/ id/A5__B_Ringkasan_Kajian_Kesehatan_REV.pdf

7. Escamilla P, Ana M. Food insecurity measurement and indicators. Rev Nutr. 2008;21(suppl.):15-26.

8. Maxwell S, Frankerberger T. Household food security: concepts, indicators, measurements; a technical review. New York: International fund for agricultural development; 1992.

9. Ariyani D, Achadi E, Irawati A. Validitas lingkar lengan atas mendeteksi risiko kekurangan energi kronis pada wanita indonesia. J Kesehat Masy Nas. 2012;7(2):83-90.

10. Purwantini TB. Pendekatan rawan pangan dan gizi: besaran, karakteristik, dan penyebabnya. Forum Penelit Agro Ekon. 2014;32(1):1-17.

11. World Food Programme. Distiquishing between chronic and transitory food insecurity in memergency needs assessments. Word Food Programme. Rome; 2006.

12. World Food Programme. Food consumption analysis - calculation and use of the food consumption score in food security analysis. Technical Guidance Sheet. Rome: United Nations World Food Programme; 2008. 1-24 p.

13. UNHCR, UNICEF, WFP. Vulnerability assessment of Syrian Refugees in Lebanon 2016. World Food Programme; 2016. 1-118 p.

14. World Food Programme. Comprehensive food security \& vulnerability analysis guidelines. First Edit. World Food Programme. Rome; 2009. 27 p.

15. Baumann SM. Measuring food security in Laos. Validation of the World Food Programme's Food Consumption Score for the Lao Context. 2010; 2005-7.
16. Tiwari S, Skoufias E, Sherpa M. Shorter, cheaper, quicker, better: linking measures of household food security to nutritional outcomes in Bangladesh, Nepal, Pakistan, Uganda, and Tanzania. Washington DC; 2013.

17. Lovon M, Mathiassen A. Are the world food programme's food consumption groups a good proxy for energy deficiency? Food Secur. 2014;6(4):461-70.

18. Wiesmann D, Bassett L, Benson T, Hoddinott J. Validation of the world food programme's food consumption score and alternative indicators of household food security. IFPRI Discussion Paper. Washington DC; 2009.

19. Sembiring AC, Briawan D, Baliwati F. Metode skor konsumsi pangan untuk menilai ketahanan pangan rumah tangga. J Penelit Gizi dan Makanan. 2015;38(1):31-40.

20. Standing Committee on the Scientific Evaluation of Dietary Reference Intakes. Dietary reference intakes. Nutrition reviews. 1997. 319-326 p.

21. Hardinsyah, Riyadi H, Napitupulu V. Kecukupan energi, protein, lemak dan karbohidrat. Dalam: Widyakarya nasional pangan dan gizi X. 2012.

22. Hoddinott J, Yohannes Y. Dietary diversity as a household food security indicator. International Food Policy Research Institute. Washington, D.C. 2002.

23. Palacios C, Rivas-Tumanyan S, SantiagoRodriguez EJ, Sinigaglia O, Rios EM, Campos $\mathrm{M}$, et al. A semi-quantitative food frequency questionnaire validated in hispanic infants and toddlers aged 0 to 24 months. J Acad Nutr Diet. 2017;117(4):526-535.e9.

24. Saaka M, Osman SM. Does household food insecurity affect the nutritional status of preschool children aged 6-36 months?. Int J Popul Res. 2013;2013:1-12. 